\title{
Management of aneurysmal subarachnoid hemorrhage
}

\author{
Michael N. Diringer, MD, FCCM, FAHA \\ Neurology/Neurosurgery Intensive Care Unit, Department of Neurology and Neurological \\ Surgery, Washington University St. Louis, MO
}

\begin{abstract}
Objective-Acute aneurysmal subarachnoid hemorrhage (SAH) is a complex multifaceted disorder that plays out over days to weeks. Many SAH patients are seriously ill and require a prolonged ICU stay. Cardiopulmonary complications are common. The management of SAH patients focuses on the anticipation, prevention and management of these secondary complications.
\end{abstract}

Data Sources-Source data were obtained from a PubMed search of the medical literature.

Data Synthesis and Conclusion-The rupture of an intracranial aneurysm is a sudden devastating event with immediate neurologic and cardiac consequences that require stabilization to allow for early diagnostic angiography. Early complications include rebleeding, hydrocephalus, and seizures. Early repair of the aneurysm (within 1-3 days) should take place by surgical or endovascular means.

Over the first 1-2 weeks after hemorrhage, patients are at risk for delayed ischemic deficits due to vasospasm, autoregulatory failure and intravascular volume contraction. Delayed ischemia is treated with combinations of volume expansion, induced hypertension, augmentation of cardiac output, angioplasty and intra-arterial vasodilators. Subarachnoid hemorrhage is a complex disease with a prolonged course that can be particularly challenging and rewarding to the intensivist.

\section{Keywords}

aneurysm; subarachnoid hemorrhage; vasospasm; hypertension; treatment; endovascular

Acute aneurysmal subarachnoid hemorrhage ( $\mathrm{SAH})$ is a complex multifaceted disorder that plays out over days to weeks. The initial hemorrhage can be devastating and up to a quarter of patients die before reaching medical attention (1). Those that survive the initial bleed are at risk for a host of secondary insults including rebleeding (2;3), hydrocephalus (4) and delayed ischemia deficits (DID) $(5 ; 6)$. The management of SAH patients focuses on the anticipation, prevention and management of these secondary complications and thus can be particularly challenging and rewarding to the intensivist.

Intracranial aneurysms account for approximately $85 \%$ of cases of non-traumatic SAH. (7) The other causes include bleeding from other vascular malformations (arteriovenous malformations), moyamoya syndrome, coagulopathy and, rarely, extension of an intracerebral hematoma. In up to one fifth of cases, no source of bleeding is identified $(8-10)$.

Correspondence: Michael N. Diringer MD Dept. of Neurology, Campus Box 8111660 S Euclid Ave St Louis, MO 63110 Phone: 314-362-2999 Fax: 314-362-0215 diringerm@ @euro.wustl.edu.

Disclosures: Dr. Diringer receives research support from the NIH and consulting fees from Novo Nordisk 


\section{Epidemiology}

In the US, over 30,000 persons each year experience a subarachnoid hemorrhage (SAH). Intracranial aneurysms are found in $2 \%$ to $5 \%$ of all autopsies; fortunately, however, the incidence of rupture is only 2-20/100,000 individuals/year (11). Hemorrhage is more frequent in women than men $(3: 2$ ratio $)(12 ; 13)$ over the age of 40 , but the reverse is true in those younger than 40 . Peak rupture rates occur between the ages of 50 and 60 years $(14 ; 15)$.

Risk factors for SAH include hypertension, cigarette smoking (16-20), heavy alcohol consumption (21;22) and a history of SAH in first-degree relatives (23-25). Having three or more affected relatives triples the risk of SAH (26;27). In 8,680 asymptomatic individuals MRI detected an overall incidence of aneurysms in the general population of $6.8 \%$ rising to $10.5 \%$ in those with a family history of SAH (28). The specific genes involved have not yet been identified.

\section{Pathophysiology}

Both congenital and acquired factors are considered important in aneurysm development. Aneurysms have been associated with connective tissue disorders and polycystic kidneys, and are frequently found on feeding vessels of arterial venous malformations $(29 ; 30)$. Acquired factors that may contribute include atherosclerosis, hypertension and hemodynamic stress $(29 ; 30)$.

The majority of aneurysms are found in the circle of Willis at the base of the brain near bifurcations. Only about $15 \%$ of aneurysms occur in the posterior (vertebro-basilar) circulation. The most common sites of ruptured aneurysms are the takeoff of the posterior communicating artery from the internal carotid artery (41\%), anterior communicating artery/ anterior cerebral artery (34\%), and middle cerebral artery (20\%) (31). Up to $20 \%$ of patients have multiple aneurysms (32).

\section{Presentation}

The classic presentation of acute aneurysm rupture is the instantaneous onset of a severe headache (33), which the patient often describes as the "worst headache of my life," nausea, vomiting and syncope followed by a gradual improvement in level of consciousness(34). Focal neurological signs are unusual but may occasionally be seen due to mass effect from a giant aneurysm, parenchymal hemorrhage, subdural hematoma or a large localized subarachnoid clot. In addition, third and sixth cranial nerve palsies may be present due to aneurysmal compression of the nerve or increased intracranial pressure, respectively. Seizures at onset may be reported (35), but it is not clear how many of these episodes represent true epileptic events vs. simple abnormal posturing.

\section{Initial and Evaluation Management}

The initial steps in the evaluation of a patient with suspected SAH should focus on airway evaluation, early CT imaging, blood pressure control, serial assessment of neurological function and preparation for angiography. The patient's clinical status is assessed using the Hunt and Hess Scale (36) and World Federation of Neurological Surgeons Scales (37) (Table 1).

A non-contrast CT scan within 24 hours detects $>95 \%$ of subarachnoid hemorrhages(38). Blood appears as a high-density signal in the cisterns surrounding the brainstem and the basal cisterns. CT may be falsely negative if the volume of blood is very small, if the 
hemorrhage occurred several days prior or if the hematocrit is extremely low. The amount of subarachnoid blood is graded (39-41) and is an important predictor of vasospasm risk (Figure 1). Early hydrocephalus is suggested by enlargement of the third ventricle and of the temporal horns of the lateral ventricles.

If CT is normal and suspicion of SAH remains strong, a lumbar puncture (LP) should be performed (42). The presence of xanthochromia may be helpful in distinguishing a traumatic lumbar puncture from a true SAH especially if it is detected by spectrophotometry (43-45).

Conventional catheter angiography remains the gold standard for detection of intracranial aneurysms and should be performed as soon as practical to facilitate early repair of the ruptured aneurysm. CT angiography has recently improved to the point where some centers use it as the primary test to indentify an aneurysm (46;47). MRI techniques are rapidly advancing to this point as well.

Angiography fails to demonstrate the cause of non-traumatic subarachnoid hemorrhage in approximately $15 \%$ to $20 \%$ of cases (48). Repeat angiography should be performed within a few days to weeks. Patients with a high quality complete angiogram that does not identify a source of bleeding have a very low incidence of rebleeding, especially if the blood is limited to the perimesencephalic and ambient cisterns $(8 ; 9 ; 49)$.

If the patient is lethargic or agitated, management of the airway should be addressed. Consideration should be given to elective intubation of agitated patients to facilitate performing safe and rapid angiography.

Blood pressure is often elevated following SAH due to pain and anxiety and generalized sympathetic activation (50). To prevent aneurysmal re-rupture, hypertension requires prompt treatment. Analgesics alone may be effective; otherwise rapidly acting antihypertensives are needed. The preferred agents include labetalol, $\beta$-blockers, hydralazine and nicardipine (51-53). A notable exception to vigorous treatment of hypertension is when hydrocephalus is present. In that situation blood pressure should be addressed after the hydrocephalus is treated.

Cardiac abnormalities are common in the first 48 hours after SAH. Electrocardiographic changes including tall peaked T-waves or cerebral T-waves, ST segment depression, and prolonged QT segments are frequent (54-56). Cardiac enzymes are often mildly elevated $(57 ; 58)$. Arrhythmias are very common but typically benign.

In rare cases, the cardiac abnormities are much more severe. Myocardial contractility may be markedly impaired, leading to a fall in cardiac output and blood pressure and pulmonary edema (59-61). This condition has been referred to as "stunned myocardium," but also may include an element of neurogenic pulmonary edema (62). The typical pattern on echocardiography is that of Tako-tsubo cardiomyopathy (63), and management is similar to other causes of acute pump failure with inotropic agents, diuretics, high concentrations of oxygen and PEEP (64-66). Troponin levels are frequently elevated and variably associated with echocardiographic abnormalities (67). The condition is surprisingly transient and completely reversed in a few days $(57 ; 58)$. In patients with known coronary artery disease, the pattern of echocardiographic changes is often helpful in determining the etiology $(50 ; 68)$. The most important predictors of cardiac dysfunction are those that reflect the severity of the hemorrhage $(64 ; 69)$. 


\section{Early Critical Care Management}

The routine monitoring of all acute SAH patients should include serial neurological examinations, continuous EKG monitoring, and frequent determinations of blood pressure, electrolytes, body weight, fluid balance, and, in many centers, transcranial doppler (TCD) (70-72). Volume status should be closely monitored and adequate hydration with isotonic saline provided to avoid volume contraction (73-75).

\section{Anticonvulsants}

The risk and implications of seizures associated with SAH are not well defined, and the need and efficacy for routinely administered anticonvulsants following SAH are not well established. It is unclear whether abnormal movements at the time of aneurysm rupture are epileptic in origin. Patients with parenchymal hematoma may be at higher risk (76-78).

Recently the routine use of anticonvulsants has been associated with cognitive impairment in SAH patients $(79 ; 80)$ and heralded the growing acceptance of reduced use of anticonvulsants. It appears that short term ( 3 day) use during the peri-operative period does not increase risk of seizures (81).

\section{Steroids}

Dexamethasone is widely used to reduce meningeal irritation and intra- and postoperative edema, but there is no convincing evidence documenting its efficacy. A recent Cochrane review concluded that there is no evidence of a beneficial or adverse effect of corticosteroids in patients with SAH (82).

\section{Rebleeding}

The risk of rebleeding is highest immediately following hemorrhage ( $4 \%$ to $6 \%$ over the first 24 hours) and declines over the next few days $(83 ; 84)$. Rates are highest in women and those with a poor clinical grade, in poor medical condition, and with elevated systolic blood pressure. Over half of the patients who rebleed die.

In the days of delayed surgery, antifibrinolytic agents were routinely administered to prevent re-bleeding (85). While they reduced the incidence of rebleeding, this benefit was offset by an increase in ischemic infarctions so there was no overall effect on outcome $(86 ; 87)$. Short term ( 3 day) use of antifibrinolytics may prevent rebleeding without increased risk of vasospasm $(88 ; 89)$.

Prior to aneurysm repair, factors associated with rebleeding (cough, valsalva) should be minimized. Rapid drainage of a large volume of CSF during lumbar puncture or ventriculostomy should be avoided. Excessive stimulation should be minimized. Headache should be controlled. Agitated patients should be sedated with short acting agents to the point of drowsiness, but should remain responsive for assessment of neurologic status. Care must be taken to avoid over sedation that could mask clinical deterioration.

Definitive prevention of rebleeding is by repair of the aneurysm, either by a surgical or endovascular approach (Figure 2). Outcome in a large prospective controlled trial found that for patients appropriate for either modality, 1-year outcome was better with endovascular coiling $(90 ; 91)$. The study has generated considerable controversy. Follow up of patients enrolled in this study revealed that patients treated with endovascular coiling were 6.9 times more likely to undergo retreatment over a mean interval of 21 months because of aneurysm recurrence or rebleeding (92). Long term rebleeding rates remain an unresolved concern (93-97). 


\section{Hydrocephalus}

Early (within 3 days) hydrocephalus (Figure 3) occurs in 20-30\% of patients and is often accompanied by intraventricular blood. Hydrocephalus is more frequent in patients with poor clinical grade and more subarachnoid blood (98-100). Clinical improvement is seen in the majority after external ventricular drainage (EVD).

Delayed (up to several weeks) hydrocephalus develops in about one-fourth of surviving patients and is associated with older age, early ventriculomegaly, ventricular hemorrhage, poor clinical condition on presentation and female gender $(101 ; 102)$. Hydrocephalus rates are no different in patients undergoing clipping or endovascular treatment of their aneurysms.

\section{LATE COMPLICATIONS}

\section{Hyponatremia and Intravascular Volume Contraction}

Hyponatremia occurs in up to one-third of patients following SAH. Although originally attributed to the syndrome of inappropriate secretion of antidiuretic hormone (SIADH), the picture is more complex (75;103-106). There are disturbances of humoral and neural regulation of sodium, intravascular volume and water in SAH that lead to intravascular volume depletion and hyponatremia, sometimes referred to as cerebral salt wasting $(104 ; 107)$. Reduced intravascular volume has been associated with clinical symptoms in patients with angiographic vasospasm. Hypervolemic therapy appears to ameliorate the tendency toward intravascular volume contraction (75).

Hyponatremia can frequently be managed with restriction of free water by giving only isotonic intravenous fluids, minimizing oral liquids and using concentrated enteral feedings. Persistent hyponatremia can be treated by utilizing mildly hypertonic solutions $(1.25-3.0 \%$ saline) as the sole intravenous fluid. Two randomized, controlled trials of fludrocortisone failed to show any important benefit (108-111).

\section{Vasospasm}

In the context of SAH, The term "vasospasm" refers to a condition that is more complex than simple constriction of blood vessels. Pathological changes occur in intracranial arteries following SAH that thicken the wall, narrow the lumen and impair relaxation (112). This, along with vasoconstriction leads to additional lumen narrowing, impaired vascular reactivity and a fall in cerebral blood flow. If the reduction in flow is severe enough, ischemia and infarction follow (113). The term "delayed ischemic neurologic deficit" (DIND) describes the clinical situation where these multiple factors conspire to produce ischemia (114-116).

Monitoring for vasospasm typically consists of serial neurologic exams, serial measurement of blood flow velocities by transcranial Doppler $(71 ; 72 ; 117-119)$ and catheter angiography. Neurologic signs may be vague, such as a global decline in responsiveness, or consist of focal deficits such as hemiparesis, hemiplegia, abulia, or language disturbance that may wax and wane (120). Transcranial Doppler is a non-invasive method that detects elevation in linear blood flow velocities (LBFV), mainly in middle and internal cerebral arteries $(72 ; 119 ; 121 ; 122)$. Although it is almost as sensitive as angiography in detecting symptomatic vasospasm, its use has limitations including inadequate insonation windows in some patients and poor specificity (123). Additionally, improving cerebral blood flow with induced hypertension leads to increased LBFV which can be misinterpreted as worsening vasospasm (124). 
When making a clinical diagnosis of vasospasm, alternative causes of neurologic changes such as sedatives, rebleeding, hydrocephalus, cerebral edema, metabolic derangements and infections should be promptly excluded using radiographic, clinical and laboratory assessments. Detection of clinical signs of vasospasm is particularly difficult in poor grade patients because of the limited exam that is possible.

The utility of other imaging modalities, like perfusion computed tomography, Xenon computed tomography, diffusion weighted magnetic resonance imaging, and single photon emission computed tomography (SPECT) in detecting vasospasm is under investigation. Cerebral microdialysis, which involves measuring extracellular cerebral fluid levels of glucose, glutamate, lactate, and pyruvate, and brain tissue oxygen tension monitoring may offer promise (125-127).

\section{Management of vasospasm}

The management of vasospasm involves both routine "prophylactic" measures and more aggressive intervention reserved for situations where there are signs or symptoms of active vasospasm.

Nimodipine is safe, cost-effective, and reduces the risk of poor outcome and secondary ischemia $(53 ; 128-130)$. It is thus used prophylactically in all patients with SAH.

Hypotension is infrequent, especially if patients are well hydrated. In those being treated with vasopressors for symptomatic vasospasm, dips in blood pressure following nimodipine administration may be more of a problem and administering small, more frequent does is helpful.

While there is general agreement that hypovolemia must be avoided, the use of prophylactic hypervolemia is more controversial (116;131-134). In a prospective controlled study, prophylactic volume expansion with albumin failed to reduce the incidence of clinical or TCD-defined vasospasm, did not improve CBF, and had no effect on outcome (135). Costs and complications may be higher with the use of prophylactic hypervolemia.

The amount of blood in the subarachnoid space is a strong predictor of vasospasm, and several methods have been proposed to facilitate its clearance. A meta-analysis found a clinically relevant and beneficial effect of intracisternal thrombolysis, but the findings were limited by the predominance of nonrandomized studies (136). Another technique uses lumbar CSF drainage (137).

Other approaches under investigation include insertion of prolonged release implants impregnated with vasodilators (papaverine and nicardipine); enoxaparin (138); and prophylactic transluminal balloon angioplasty (139).

The threshold for instituting more aggressive interventions varies widely across centers. Some actively intervene in the setting of rising TCD velocities (124) or angiographic vasospasm in asymptomatic patients (140), while others institute aggressive measures in the setting of neurological deterioration.

Aggressive measures include both hemodynamic and endovascular manipulations (141-143). The goal is to improve CBF in ischemic regions. Since SAH patients tend to become hypovolemic and lose pressure autoregulation(144-146), it has been inferred that hypervolemia, induced hypertension and augmentation of cardiac output would accomplish that goal.

The use of triple-H therapy (hypervolemia, hypertension and hemodilution) stems from numerous clinical observations noting improvement in patients' clinical symptoms 
following induced hypertension and volume expansion (147-149). The relative contribution of each component is debated.

Despite being widely advocated, data supporting the use of hypervolemia are scant. A prospective randomized trial found no impact of prophylactic hypervolemia on CBF, vasospasm or outcome (135). Other studies question whether hypervolemia adds further benefit beyond correction of hypovolemia (150-152) and report that the impact of volume expansion on $\mathrm{CBF}$ is modest compared to induced hypertension (153).

Hemodilution is perhaps the least understood component of triple- $\mathrm{H}$ therapy. The rationale is to reduce blood viscosity to augment CBF. The trade off is that oxygen carrying capacity is reduced, potentially diminishing cerebral oxygen delivery. It is argued that a hematocrit of $30 \%$ provides the optimal balance between oxygen carrying capacity and viscosity. One study found that despite a rise in CBF, oxygen delivery fell with hemodilution to this level, suggesting that it produced more harm than good (154).

Blood pressure augmentation by raising pressure by a percent of baseline or to an arbitrary goal may be the most effective hemodynamic intervention. Studies have found a consistent rise in CBF in response to blood pressure elevation with dopamine and phenylephrine, although they have not yet identified the optimal target $(155 ; 156)$.

Under normal conditions, changes in cardiac output (CO) do not influence CBF. There is growing evidence, however, that with cerebral ischemia or impaired autoregulation, changes in $\mathrm{CO}$ can alter $\mathrm{CBF}$. Administration of dobutamine or milrinone may be effective in improving cardiac output and CBF in some patients (156-159).

Endovascular techniques frequently play a role in the aggressive treatment of vasospasm. They include transluminal angioplasty (Figure 4) and intra-arterial infusion of vasodilators. Both methods have their unique associated risks and benefits and are usually undertaken after a trial of medical therapy, except in patients with severe cardiac disease.

Transluminal balloon angioplasty is very effective at reversing angiographic spasm of large proximal vessels and produces a sustained reversal of arterial narrowing (160-163). The optimal timing of angioplasty in relation to medical therapy is uncertain. Major complications occur in $\sim 5 \%$ of procedures and include vessel rupture, occlusion, dissection, hemorrhagic infarction and hemorrhage from unsecured aneurysms (164).

Intra-arterial papaverine has an immediate and dramatic effect on blood vessels, but reversal of clinical deficits is variable (165-167). In most centers, use of papaverine has been abandoned because of its short lived effect and complications including increased intracranial pressure, apnea, worsening of vasospasm, neurological deterioration and seizures. This has led to growing use of intra-arterial nicardipine, verapamil, nimodipine, and milrinone as alternatives to papaverine (168-170).

\section{Acknowledgments}

Support: NIH 5P01NS035966

\section{Reference List}

1. Heros RC, Kistler JP. Intracranial arterial aneurysm-an update. Stroke 1983;14:628-631. [PubMed: 6658944] 
2. Winn HR, Richardson AE, Jane JA. The long-term prognosis in untreated cerebral aneurysms: I. The incidence of late hemorrhage in cerebral aneurysm: a 10-year evaluation of 364 patients. Ann Neurol 1977;1(4):358-370. [PubMed: 617253]

3. Ohkuma H, Tsurutani H, Suzuki S. Incidence and significance of early aneurysmal rebleeding before neurosurgical or neurological management. Stroke 2001;32(5):1176-1180. [PubMed: 11340229]

4. Mohr, JP.; Kistler, JP. Intracranial aneurysms.. In: Mohr, JP., editor. Stroke: pathophysiology, diagnosis and management. Chruchill Livingstone; London: 1985. p. 643-677.!Lost Data, !Lost Data!Lost Data

5. Rabinstein AA, Weigand S, Atkinson JL, Wijdicks EF. Patterns of cerebral infarction in aneurysmal subarachnoid hemorrhage. Stroke 2005;36(5):992-997. [PubMed: 15831836]

6. Hijdra A, van Gijn J, Stefanko S, van Dongen KJ, Vermeulen M, van Crevel H. Delayed cerebral ischemia after aneurysmal subarachnoid hemorrhage: clinicoanatomic correlations. Neurology 1986;36(3):329-333. [PubMed: 3951698]

7. van Gijn J, Kerr RS, Rinkel GJ. Subarachnoid haemorrhage. Lancet 2007;369(9558):306-318. [PubMed: 17258671]

8. van Gijn J, van Dongen KJ, Vermeulen M, Hijdra A. Perimesencephalic hemorrhage. J Neurosurg 1986;65(5):727-728. [PubMed: 3772468]

9. Ruigrok YM, Rinkel GJ, Buskens E, Velthuis BK, van Gijn J. Perimesencephalic hemorrhage and CT angiography: A decision analysis. Stroke 2000;31(12):2976-2983. [PubMed: 11108759]

10. van Gijn J, van Dongen KJ, Vermeulen M, Hijdra A. Perimesencephalic hemorrhage: a nonaneurysmal and benign form of subarachnoid hemorrhage. Neurology 1985;35(4):493-497. [PubMed: 3982634]

11. Ingall T, Asplund K, Mahonen M, Bonita R. A multinational comparison of subarachnoid hemorrhage epidemiology in the WHO MONICA stroke study. Stroke 2000;31(5):1054-1061. [PubMed: 10797165]

12. Epidemiology of aneurysmal subarachnoid hemorrhage in Australia and New Zealand: incidence and case fatality from the Australasian Cooperative Research on Subarachnoid Hemorrhage Study (ACROSS). Stroke 2000;31(8):1843-1850. [PubMed: 10926945]

13. Ohkuma H, Fujita S, Suzuki S. Incidence of aneurysmal subarachnoid hemorrhage in Shimokita, Japan, from 1989 to 1998. Stroke 2002;33(1):195-199. [PubMed: 11779910]

14. Epidemiology of aneurysmal subarachnoid hemorrhage in Australia and New Zealand: incidence and case fatality from the Australasian Cooperative Research on Subarachnoid Hemorrhage Study (ACROSS). Stroke 2000;31(8):1843-1850. [PubMed: 10926945]

15. Ohkuma H, Fujita S, Suzuki S. Incidence of aneurysmal subarachnoid hemorrhage in Shimokita, Japan, from 1989 to 1998. Stroke 2002;33(1):195-199. [PubMed: 11779910]

16. Kawachi I, Colditz GA, Stampfer MJ, Willett WC, Manson JE, Rosner B, et al. Smoking cessation and decreased risk of stroke in women. JAMA 1993;269(2):232-236. [PubMed: 8417241]

17. Kawachi I, Colditz GA, Stampfer MJ, Willett WC, Manson JE, Rosner B, et al. Smoking cessation and decreased risk of stroke in women. JAMA 1993;269(2):232-236. [PubMed: 8417241]

18. Qureshi AI, Suarez JI, Parekh PD, Sung G, Geocadin R, Bhardwaj A, et al. Risk factors for multiple intracranial aneurysms. Neurosurgery 1998;43(1):22-26. [PubMed: 9657184]

19. Juvela S. Risk factors for multiple intracranial aneurysms. Stroke 2000;31(2):392-397. [PubMed: 10657411]

20. Ellamushi HE, Grieve JP, Jager HR, Kitchen ND. Risk factors for the formation of multiple intracranial aneurysms. J Neurosurg 2001;94(5):728-732. [PubMed: 11354403]

21. Taylor CL, Yuan Z, Selman WR, Ratcheson RA, Rimm AA. Cerebral arterial aneurysm formation and rupture in 20,767 elderly patients: hypertension and other risk factors. J Neurosurg 1995;83(5):812-819. [PubMed: 7472548]

22. Qureshi AI, Suri MF, Yahia AM, Suarez JI, Guterman LR, Hopkins LN, et al. Risk factors for subarachnoid hemorrhage. Neurosurgery 2001;49(3):607-612. [PubMed: 11523670]

23. Kojima M, Nagasawa S, Lee YE, Takeichi Y, Tsuda E, Mabuchi N. Asymptomatic familial cerebral aneurysms. Neurosurgery 1998;43(4):776-781. [PubMed: 9766303] 
24. Raaymakers TW. Aneurysms in relatives of patients with subarachnoid hemorrhage: frequency and risk factors. MARS Study Group. Magnetic Resonance Angiography in Relatives of patients with Subarachnoid hemorrhage. Neurology 1999;53(5):982-988. [PubMed: 10496256]

25. Kissela BM, Sauerbeck L, Woo D, Khoury J, Carrozzella J, Pancioli A, et al. Subarachnoid hemorrhage: a preventable disease with a heritable component. Stroke 2002;33(5):1321-1326. [PubMed: 11988610]

26. Epidemiology of aneurysmal subarachnoid hemorrhage in Australia and New Zealand: incidence and case fatality from the Australasian Cooperative Research on Subarachnoid Hemorrhage Study (ACROSS). Stroke 2000;31(8):1843-1850. [PubMed: 10926945]

27. Ohkuma H, Fujita S, Suzuki S. Incidence of aneurysmal subarachnoid hemorrhage in Shimokita, Japan, from 1989 to 1998. Stroke 2002;33(1):195-199. [PubMed: 11779910]

28. Kojima M, Nagasawa S, Lee YE, Takeichi Y, Tsuda E, Mabuchi N. Asymptomatic familial cerebral aneurysms. Neurosurgery 1998;43(4):776-781. [PubMed: 9766303]

29. Sekhar LN, Heros RC. Origin, growth, and rupture of saccular aneurysms: a review. Neurosurgery 1981;8(2):248-260. [PubMed: 7010205]

30. Crawford PM, West CR, Chadwick DW, Shaw MD. Arteriovenous malformations of the brain: natural history in unoperated patients. J Neurol Neurosurg Psychiatry 1986;49(1):1-10. [PubMed: 3958721]

31. van Gijn J, Kerr RS, Rinkel GJ. Subarachnoid haemorrhage. Lancet 2007;369(9558):306-318. [PubMed: 17258671]

32. Nehls DG, Flom RA, Carter LP, Spetzler RF. Multiple intracranial aneurysms: determining the site of rupture. J Neurosurg 1985;63(3):342-348. [PubMed: 4020459]

33. Linn FH, Rinkel GJ, Algra A, van Gijn J. Headache characteristics in subarachnoid haemorrhage and benign thunderclap headache. J Neurol Neurosurg Psychiatry 1998;65(5):791-793. [PubMed: 9810961]

34. Waga S, Otsubo K, Handa H. Warning signs in intracranial aneurysms. Surg Neurol 1975;3(1):1520. [PubMed: 1111139]

35. Hart RG, Byer JA, Slaughter JR, Hewett JE, Easton JD. Occurrence and implications of seizures in subarachnoid hemorrhage due to ruptured intracranial aneurysms. Neurosurgery 1981;8(4):417421. [PubMed: 7242892]

36. Hunt WE, Hess RM. Surgical risk as related to time of intervention in the repair of intracranial aneurysms. J Neurosurg 1968;28(1):14-20. [PubMed: 5635959]

37. Report of World Federation of Neurological Surgeons Committee on a Universal Subarachnoid Hemorrhage Grading Scale. J Neurosurg 1988;68(6):985-986. [PubMed: 3131498]

38. Boesiger BM, Shiber JR. Subarachnoid hemorrhage diagnosis by computed tomography and lumbar puncture: are fifth generation CT scanners better at identifying subarachnoid hemorrhage? J Emerg Med 2005;29(1):23-27. [PubMed: 15961003]

39. Frontera JA, Claassen J, Schmidt JM, Wartenberg KE, Temes R, Connolly ES Jr, et al. Prediction of symptomatic vasospasm after subarachnoid hemorrhage: the modified fisher scale. Neurosurgery 2006;59(1):21-27. [PubMed: 16823296]

40. Smith ML, Abrahams JM, Chandela S, Smith MJ, Hurst RW, Le Roux PD. Subarachnoid hemorrhage on computed tomography scanning and the development of cerebral vasospasm: the Fisher grade revisited. Surg Neurol 2005;63(3):229-234. [PubMed: 15734507]

41. Klimo P Jr. Schmidt RH. Computed tomography grading schemes used to predict cerebral vasospasm after aneurysmal subarachnoid hemorrhage: a historical review. Neurosurg Focus 2006;21(3):E5. [PubMed: 17029344]

42. van der WN, Rinkel GJ, Hasan D, van Gijn J. Detection of subarachnoid haemorrhage on early CT: is lumbar puncture still needed after a negative scan? J Neurol Neurosurg Psychiatry 1995;58(3): 357-359. [PubMed: 7897421]

43. Beetham R. Recommendations for CSF analysis in subarachnoid haemorrhage. J Neurol Neurosurg Psychiatry 2004;75(4):528. [PubMed: 15026489]

44. Cruickshank AM. ACP Best Practice No 166: CSF spectrophotometry in the diagnosis of subarachnoid haemorrhage. J Clin Pathol 2001;54(11):827-830. [PubMed: 11684714] 
45. Beetham R, Fahie-Wilson MN, Holbrook I, Thomas P, Ward AM, Watson ID, et al. CSF spectrophotometry in the diagnosis of subarachnoid haemorrhage. J Clin Pathol 2002;55(6):479_ 480. [PubMed: 12037038]

46. Villablanca JP, Martin N, Jahan R, Gobin YP, Frazee, Duckwiler G, et al. Volume-rendered helical computerized tomography angiography in the detection and characterization of intracranial aneurysms. J Neurosurg 2000;93(2):254-264. [PubMed: 10930011]

47. Velthuis BK, Van Leeuwen MS, Witkamp TD, Ramos LM, Berkelbach van Der Sprenkel JW, Rinkel GJ. Computerized tomography angiography in patients with subarachnoid hemorrhage: from aneurysm detection to treatment without conventional angiography. J Neurosurg 1999;91(5): 761-767. [PubMed: 10541232]

48. Qu F, Aiyagari V, Cross DT III, Dacey RG Jr. Diringer MN. Untreated subarachnoid hemorrhage: who, why, and when? J Neurosurg 2004;100(2):244-249. [PubMed: 15086231]

49. van Gijn J, van Dongen KJ, Vermeulen M, Hijdra A. Perimesencephalic hemorrhage: a nonaneurysmal and benign form of subarachnoid hemorrhage. Neurology 1985;35(4):493-497. [PubMed: 3982634]

50. Tung P, Kopelnik A, Banki N, Ong K, Ko N, Lawton MT, et al. Predictors of neurocardiogenic injury after subarachnoid hemorrhage. Stroke 2004;35(2):548-551. [PubMed: 14739408]

51. Liu-Deryke X, Janisse J, Coplin WM, Parker D Jr. Norris G, Rhoney DH. A Comparison of Nicardipine and Labetalol for Acute Hypertension Management Following Stroke. Neurocrit Care. 2008

52. Rose JC, Mayer SA. Optimizing blood pressure in neurological emergencies. Neurocrit Care 2004;1(3):287-299. [PubMed: 16174926]

53. Mee E, Dorrance D, Lowe D, Neil Dwyer G. Controlled study of nimodipine in aneurysm patients treated early after subarachnoid hemorrhage. Neurosurgery 1988;22:484-491. [PubMed: 3283595]

54. Galloon S, Rees GA, Briscoe CE, Davies S, Kilpatrick GS. Prospective study of electrocardiographic changes associated with subarachnoid haemorrhage. Br J Anaesth 1972;44:511-516. [PubMed: 5044081]

55. Grad A, Kiauta T, Osredkar J. Effect of elevated plasma norepinephrine on electrocardiographic changes in subarachnoid hemorrhage. Stroke 1991;22:746-749. [PubMed: 2057973]

56. Yamaguchi T, Shimizu Y, Ono N, Unno M, Nishikawa H, Kakuta Y, et al. A case of subarachnoid hemorrhage with electrocardiographic and echocardiographic changes simulating transmural myocardial infarction. Jpn J Med 1991;30:142-145. [PubMed: 1865586]

57. Deibert E, Barzilai B, Braverman AC, Edwards DF, Aiyagari V, Dacey R, et al. Clinical significance of elevated troponin I levels in patients with nontraumatic subarachnoid hemorrhage. J Neurosurg 2003;98(4):741-746. [PubMed: 12691398]

58. Deibert E, Aiyagari V, Diringer MN. Reversible left ventricular dysfunction associated with raised troponin I after subarachnoid haemorrhage does not preclude successful heart transplantation. Heart 2000;84(2):205-207. [PubMed: 10908262]

59. Wartenberg KE, Mayer SA. Medical complications after subarachnoid hemorrhage: new strategies for prevention and management. Curr Opin Crit Care 2006;12(2):78-84. [PubMed: 16543780]

60. Jain R, Deveikis J, Thompson BG. Management of patients with stunned myocardium associated with subarachnoid hemorrhage. AJNR Am J Neuroradiol 2004;25(1):126-129. [PubMed: 14729541]

61. Hammermeister KE, Reichenbach DD. QRS changes, pulmonary edema, and myocardial necrosis associated with subarachnoid hemorrhage. Am Heart J 1969;78(1):94-100. [PubMed: 5794802]

62. Takahashi M, Mitsuhashi T, Katsuki T, Ikeda U, Tanaka H, Kusaka G, et al. Neurogenic pulmonary edema and large negative $\mathrm{T}$ waves associated with subarachnoid hemorrhage. Intern Med 2001;40(8):826-828. [PubMed: 11518136]

63. Das M, Gonsalves S, Saha A, Ross S, Williams G. Acute subarachnoid haemorrhage as a precipitant for takotsubo cardiomyopathy: A case report and discussion. Int J Cardiol. 2007

64. Stevens RD, Nyquist PA. The systemic implications of aneurysmal subarachnoid hemorrhage. J Neurol Sci 2007;261(1-2):143-156. [PubMed: 17544451] 
65. Sugimoto K, Watanabe E, Yamada A, Iwase M, Sano H, Hishida H, et al. Prognostic implications of left ventricular wall motion abnormalities associated with subarachnoid hemorrhage. Int Heart J 2008;49(1):75-85. [PubMed: 18360066]

66. Wartenberg KE, Mayer SA. Medical complications after subarachnoid hemorrhage: new strategies for prevention and management. Curr Opin Crit Care 2006;12(2):78-84. [PubMed: 16543780]

67. Banki NM, Kopelnik A, Dae MW, Miss J, Tung P, Lawton MT, et al. Acute neurocardiogenic injury after subarachnoid hemorrhage. Circulation 2005;112(21):3314-3319. [PubMed: 16286583]

68. Davies KR, Gelb AW, Manninen PH, Boughner DR, Bisnaire D. Cardiac function in aneurysmal subarachnoid haemorrhage: a study of electrocardiographic and echocardiographic abnormalities. Br J Anaesth 1991;67:58-63. [PubMed: 1859761]

69. Kopelnik A, Fisher L, Miss JC, Banki N, Tung P, Lawton MT, et al. Prevalence and implications of diastolic dysfunction after subarachnoid hemorrhage. Neurocrit Care 2005;3(2):132-138. [PubMed: 16174882]

70. Newell DW, Grady MS, Eskridge JM, Winn HR. Distribution of angiographic vasospasm after subarachnoid hemorrhage: implications for diagnosis by transcranial Doppler ultrasonography. Neurosurgery 1990;27:574-577. [PubMed: 2234360]

71. Sloan MA, Haley EC Jr. Kassell NF, Henry ML, Stewart SR, Beskin RR, et al. Sensitivity and specificity of transcranial doppler ultrasonography in the diagnosis of vasospasm following subarachnoid hemorrhage. Neurology 1989;39:1514-1518. [PubMed: 2682350]

72. Sekhar LN, Wechsler LR, Yonas H, Luyckx K, Obrist W. Value of transcranial Doppler examination in the diagnosis of cerebral vasospasm after subarachnoid hemorrhage. Neurosurgery 1988;22:813-821. [PubMed: 3288899]

73. Keyrouz SG, Diringer MN. Clinical review: Prevention and therapy of vasospasm in subarachnoid hemorrhage. Crit Care 2007;11(4):220. [PubMed: 17705883]

74. Diringer MN, Axelrod Y. Hemodynamic manipulation in the neuro-intensive care unit: cerebral perfusion pressure therapy in head injury and hemodynamic augmentation for cerebral vasospasm. Curr Opin Crit Care 2007;13(2):156-162. [PubMed: 17327736]

75. Diringer MN, Wu KC, Verbalis JG, Hanley DF. Hypervolemic therapy prevents volume contraction but not hyponatremia following subarachnoid hemorrhage. Ann Neurol 1992;31(5): 543-550. [PubMed: 1534478]

76. Kvam DA, Loftus CM, Copeland B, Quest DO. Seizures during the immediate post operative period. Neurosurg 1983;12:14-17.

77. Rose FC, Sarner M. Epilepsy after ruptured intracranial aneurysm. Brit Med J 1965;1:18-21. [PubMed: 14213094]

78. Cabral RJ, King TT, Scott DF. Epilepsy after two different neurosurgical approaches to treatment of ruptured intracranial aneurysm. J Neurol Neurosurg Psych 1976;39:1052-1056.

79. Rosengart AJ, Huo JD, Tolentino J, Novakovic RL, Frank JI, Goldenberg FD, et al. Outcome in patients with subarachnoid hemorrhage treated with antiepileptic drugs. J Neurosurg 2007;107(2): 253-260. [PubMed: 17695377]

80. Naidech AM, Kreiter KT, Janjua N, Ostapkovich N, Parra A, Commichau C, et al. Phenytoin exposure is associated with functional and cognitive disability after subarachnoid hemorrhage. Stroke 2005;36(3):583-587. [PubMed: 15662039]

81. Chumnanvej S, Dunn IF, Kim DH. Three-day phenytoin prophylaxis is adequate after subarachnoid hemorrhage. Neurosurgery 2007;60(1):99-102. [PubMed: 17228257]

82. Feigin VL, Anderson N, Rinkel GJ, Algra A, van Gijn J, Bennett DA. Corticosteroids for aneurysmal subarachnoid haemorrhage and primary intracerebral haemorrhage. Cochrane Database Syst Rev 2005;(3):CD004583. \%20. [PubMed: 16034939]

83. Winn HR, Richardson AE, Jane JA. The long-term prognosis in untreated cerebral aneurysms: I. The incidence of late hemorrhage in cerebral aneurysm: a 10-year evaluation of 364 patients. Ann Neurol 1977;1(4):358-370. [PubMed: 617253]

84. Winn HR, Almaani WS, Berga SL, Jane JA, Richardson AE. The long-term outcome in patients with multiple aneurysms. Incidence of late hemorrhage and implications for treatment of incidental aneurysms. J Neurosurg 1983;59(4):642-651. [PubMed: 6886785] 
85. Torner JC, Kassell NF. Preoperative prognostic factors for rebleeding and survuval in aneurysm patients receiving antifibrinolytic therapy: Report of the cooperatvie aneruysm study. Neurosurg 1981;9:506-511. !Lost Data, !Lost Data.

86. Roos YB, Rinkel GJ, Vermeulen M, Algra A, van Gijn J. Antifibrinolytic therapy for aneurysmal subarachnoid haemorrhage. Cochrane Database Syst Rev 2003;(2):CD001245. [PubMed: 12804399]

87. Roos Y, Rinkel G, Vermeulen M, Algra A, van Gijn J. Antifibrinolytic therapy for aneurysmal subarachnoid hemorrhage: a major update of a cochrane review. Stroke 2003;34(9):2308-2309. [PubMed: 12933970]

88. Hillman J, Fridriksson S, Nilsson O, Yu Z, Saveland H, Jakobsson KE. Immediate administration of tranexamic acid and reduced incidence of early rebleeding after aneurysmal subarachnoid hemorrhage: a prospective randomized study. J Neurosurg 2002;97(4):771-778. [PubMed: 12405362]

89. Chwajol M, Starke RM, Kim GH, Mayer SA, Connolly ES. Antifibrinolytic Therapy To Prevent Early Rebleeding After Subarachnoid Hemorrhage. Neurocrit Care. 2008

90. de Oliveira JG, Beck J, Ulrich C, Rathert J, Raabe A, Seifert V. Comparison between clipping and coiling on the incidence of cerebral vasospasm after aneurysmal subarachnoid hemorrhage: a systematic review and meta-analysis. Neurosurg Rev 2007;30(1):22-30. [PubMed: 17061137]

91. Diringer MN. To clip or to coil acutely ruptured intracranial aneurysms: update on the debate. Curr Opin Crit Care 2005;11(2):121-125. [PubMed: 15758591]

92. Campi A, Ramzi N, Molyneux AJ, Summers PE, Kerr RS, Sneade M, et al. Retreatment of ruptured cerebral aneurysms in patients randomized by coiling or clipping in the International Subarachnoid Aneurysm Trial (ISAT). Stroke 2007;38(5):1538-1544. [PubMed: 17395870]

93. Molyneux AJ, Kerr RS, Yu LM, Clarke M, Sneade M, Yarnold JA, et al. International subarachnoid aneurysm trial (ISAT) of neurosurgical clipping versus endovascular coiling in 2143 patients with ruptured intracranial aneurysms: a randomised comparison of effects on survival, dependency, seizures, rebleeding, subgroups, and aneurysm occlusion. Lancet 2005;366(9488): 809-817. [PubMed: 16139655]

94. Molyneux A, Kerr R, Stratton I, Sandercock P, Clarke M, Shrimpton J, et al. International Subarachnoid Aneurysm Trial (ISAT) of neurosurgical clipping versus endovascular coiling in 2143 patients with ruptured intracranial aneurysms: a randomised trial. Lancet 2002;360(9342): 1267-1274. [PubMed: 12414200]

95. Reeves BC, Langham J, Lindsay KW, Molyneux AJ, Browne JP, Copley L, et al. Findings of the International Subarachnoid Aneurysm Trial and the National Study of Subarachnoid Haemorrhage in context. Br J Neurosurg 2007;21(4):318-323. [PubMed: 17676447]

96. Wolstenholme J, Rivero-Arias O, Gray A, Molyneux AJ, Kerr RS, Yarnold JA, et al. Treatment pathways, resource use, and costs of endovascular coiling versus surgical clipping after aSAH. Stroke 2008;39(1):111-119. [PubMed: 18048858]

97. Mitchell P, Kerr R, Mendelow AD, Molyneux A. Could late rebleeding overturn the superiority of cranial aneurysm coil embolization over clip ligation seen in the International Subarachnoid Aneurysm Trial? J Neurosurg 2008;108(3):437-442. [PubMed: 18312088]

98. Dorai Z, Hynan LS, Kopitnik TA, Samson D. Factors related to hydrocephalus after aneurysmal subarachnoid hemorrhage. Neurosurgery 2003;52(4):763-769. [PubMed: 12657171]

99. Brisman JL, Berenstein A. Factors related to hydrocephalus after aneurysmal subarachnoid hemorrhage. Neurosurgery 2004;54(4):1031. [PubMed: 15088618]

100. Tian HL, Xu T, Hu J, Cui YH, Chen H, Zhou LF. Risk factors related to hydrocephalus after traumatic subarachnoid hemorrhage. Surg Neurol 2008;69(3):241-246. [PubMed: 17707493]

101. Tian HL, Xu T, Hu J, Cui YH, Chen H, Zhou LF. Risk factors related to hydrocephalus after traumatic subarachnoid hemorrhage. Surg Neurol 2008;69(3):241-246. [PubMed: 17707493]

102. Hirashima Y, Hamada H, Hayashi N, Kuwayama N, Origasa H, Endo S. Independent predictors of late hydrocephalus in patients with aneurysmal subarachnoid hemorrhage--analysis by multivariate logistic regression model. Cerebrovasc Dis 2003;16(3):205-210. [PubMed: 12865606] 
103. Diringer MN. Sodium disturbances frequently encountered in a neurologic intensive care unit. Neurol India 2001;49(Suppl 1):S19-S30. [PubMed: 11889473]

104. Diringer MN. Neuroendocrine regulation of sodium and volume following subarachnoid hemorrhage. Clin Neuropharmacol 1995;18(2):114-126. [PubMed: 8635171]

105. Wijdicks EFM, Vermeulen M, Hijdra A, van Gijn J. Hyponatremia and cerebral infarction in patients with ruptured intracranial aneurysms: is fluid restriction harmful. Annals of Neurology 1985;17:137-140. [PubMed: 3977297]

106. Wijdicks EFM, Vermeulen M, ten Haaf JA, Bakker WH, van Gijn J. Volume depletion and natriuresis in patients with a ruptured intracranial aneurysm. Annals of Neurology 1985;18:211216. [PubMed: 4037761]

107. Diringer MN. Management of sodium abnormalities in patients with CNS disease. Clin Neuropharmacol 1992;15(6):427-447. [PubMed: 1477846]

108. Hasan D, Lindsay KW, Wijdicks EF, Murray GD, Brouwers PJ, Bakker WH, et al. Effect of fludrocortisone acetate in patients with subarachnoid hemorrhage. Stroke 1989;20(9):1156-1161. [PubMed: 2672426]

109. Mori T, Katayama Y, Kawamata T, Hirayama T. Improved efficiency of hypervolemic therapy with inhibition of natriuresis by fludrocortisone in patients with aneurysmal subarachnoid hemorrhage. J Neurosurg 1999;91(6):947-952. [PubMed: 10584839]

110. Wijdicks EF, Vermeulen M, van Brummelen P, van Gijn J. The effect of fludrocortisone acetate on plasma volume and natriuresis in patients with aneurysmal subarachnoid hemorrhage. Clin Neurol Neurosurg 1988;90(3):209-214. [PubMed: 3197346]

111. Woo MH, Kale-Pradhan PB. Fludrocortisone in the treatment of subarachnoid hemorrhageinduced hyponatremia. Ann Pharmacother 1997;31(5):637-639. [PubMed: 9161663]

112. Seifert V, Stolke D, Reale E. Ultrastructural changes of the basilar artery following experimental subarachnoid haemorrhage. A morphological study on the pathogenesis of delayed cerebral vasospasm. Acta Neurochir (Wien) 1989;100:164-171. [PubMed: 2589124]

113. Powers WJ, Grubb RL Jr. Baker RP, Mintun MA, Raichle ME. Regional cerebral blood flow and metabolism in reversible ischemia due to vasospasm. Determination by positron emission tomography. J Neurosurg 1985;62(4):539-546. [PubMed: 3871846]

114. Keyrouz SG, Diringer MN. Clinical review: Prevention and therapy of vasospasm in subarachnoid hemorrhage. Crit Care 2007;11(4):220. [PubMed: 17705883]

115. Kirsch JR, Diringer MN, Borel CO, Hanley DF. Cerebral aneurysms: mechanisms of injury and critical care interventions. Crit Care Clin 1989;5(4):755-772. [PubMed: 2676097]

116. Miller J, Diringer M. Management of aneurysmal subarachnoid hemorrhage. Neurol Clin 1995;13(3):451-478. [PubMed: 7476815]

117. Romner B, Ljunggren B, Brandt L, Saveland H. Transcranial Doppler sonography within 12 hours after subarachnoid hemorrhage. J Neurosurg 1989;70:732-736. [PubMed: 2651585]

118. Vajkoczy P, Horn P, Thome C, Munch E, Schmiedek P. Regional cerebral blood flow monitoring in the diagnosis of delayed ischemia following aneurysmal subarachnoid hemorrhage. $\mathrm{J}$ Neurosurg 2003;98(6):1227-1234. [PubMed: 12816269]

119. Verlooy J, Heytens L, Van den Brande E, Selosse P. Transcranial Doppler sonography in subarachnoid hemorrhage. Acta Neurol Belg 1989;89:346-351. [PubMed: 2517181]

120. Kassell NF, Sasaki T, Colohan AR, Nazar G. Cerebral vasospasm following aneurysmal subarachnoid hemorrhage. Stroke 1985;16(4):562-572. [PubMed: 3895589]

121. Romner B, Ljunggren B, Brandt L, S:aveland H. Correlation of transcranial Doppler sonography findings with timing of aneurysm surgery. J Neurosurg 1990;73:72-76. [PubMed: 2191092]

122. Suarez JI, Qureshi AI, Yahia AB, Parekh PD, Tamargo RJ, Williams MA, et al. Symptomatic vasospasm diagnosis after subarachnoid hemorrhage: evaluation of transcranial Doppler ultrasound and cerebral angiography as related to compromised vascular distribution. Crit Care Med 2002;30(6):1348-1355. [PubMed: 12072693]

123. Suarez JI, Qureshi AI, Yahia AB, Parekh PD, Tamargo RJ, Williams MA, et al. Symptomatic vasospasm diagnosis after subarachnoid hemorrhage: evaluation of transcranial Doppler ultrasound and cerebral angiography as related to compromised vascular distribution. Crit Care Med 2002;30(6):1348-1355. [PubMed: 12072693] 
124. Manno EM, Gress DR, Schwamm LH, Diringer MN, Ogilvy CS. Effects of induced hypertension on transcranial Doppler ultrasound velocities in patients after subarachnoid hemorrhage. Stroke 1998;29(2):422-428. [PubMed: 9472884]

125. Skjoth-Rasmussen J, Schulz M, Kristensen SR, Bjerre P. Delayed neurological deficits detected by an ischemic pattern in the extracellular cerebral metabolites in patients with aneurysmal subarachnoid hemorrhage. J Neurosurg 2004;100(1):8-15. [PubMed: 14743906]

126. Sarrafzadeh AS, Sakowitz OW, Kiening KL, Benndorf G, Lanksch WR, Unterberg AW. Bedside microdialysis: a tool to monitor cerebral metabolism in subarachnoid hemorrhage patients? Crit Care Med 2002;30(5):1062-1070. [PubMed: 12006804]

127. Schulz MK, Wang LP, Tange M, Bjerre P. Cerebral microdialysis monitoring: determination of normal and ischemic cerebral metabolisms in patients with aneurysmal subarachnoid hemorrhage. J Neurosurg 2000;93(5):808-814. [PubMed: 11059662]

128. Kostron H, Twerdy K, Grunert V. The calcium entry blocker nimodipine improves the quality of life of patients operated on for cerebral aneurysms. A 5-year follow-up analysis. Neurochirurgia (Stuttg ) 1988;31:150-153. [PubMed: 3231282]

129. Neil Dwyer G, Mee E, Dorrance D, Lowe D. Early intervention with nimodipine in subarachnoid haemorrhage. Eur Heart J 1987;8:41-47. [PubMed: 3450521]

130. Welty TE. Use of nimodipine for prevention and treatment of cerebral arterial spasm in patients with subarachnoid hemorrhage. Clin Pharm 1987;6:940-946. [PubMed: 3322639]

131. Keyrouz SG, Diringer MN. Clinical review: Prevention and therapy of vasospasm in subarachnoid hemorrhage. Crit Care 2007;11(4):220. [PubMed: 17705883]

132. Muench E, Horn P, Bauhuf C, Roth H, Philipps M, Hermann P, et al. Effects of hypervolemia and hypertension on regional cerebral blood flow, intracranial pressure, and brain tissue oxygenation after subarachnoid hemorrhage. Crit Care Med 2007;35(8):1844-1851. [PubMed: 17581487]

133. Raabe A, Beck J, Keller M, Vatter H, Zimmermann M, Seifert V. Relative importance of hypertension compared with hypervolemia for increasing cerebral oxygenation in patients with cerebral vasospasm after subarachnoid hemorrhage. J Neurosurg 2005;103(6):974-981. [PubMed: 16381183]

134. Ekelund A, Reinstrup P, Ryding E, Andersson AM, Molund T, Kristiansson KA, et al. Effects of iso- and hypervolemic hemodilution on regional cerebral blood flow and oxygen delivery for patients with vasospasm after aneurysmal subarachnoid hemorrhage. Acta Neurochir (Wien ) 2002;144(7):703-712. [PubMed: 12181704]

135. Lennihan L, Mayer SA, Fink ME, Beckford A, Paik MC, Zhang H, et al. Effect of hypervolemic therapy on cerebral blood flow after subarachnoid hemorrhage : a randomized controlled trial. Stroke 2000;31(2):383-391. [PubMed: 10657410]

136. Amin-Hanjani S, Ogilvy CS, Barker FG. Does intracisternal thrombolysis prevent vasospasm after aneurysmal subarachnoid hemorrhage? A meta-analysis. Neurosurgery 2004;54(2):326334. [PubMed: 14744278]

137. Klimo P Jr. Kestle JR, MacDonald JD, Schmidt RH. Marked reduction of cerebral vasospasm with lumbar drainage of cerebrospinal fluid after subarachnoid hemorrhage. J Neurosurg 2004;100(2):215-224. [PubMed: 15086227]

138. Wurm G, Tomancok B, Nussbaumer K, Adelwohrer C, Holl K. Reduction of ischemic sequelae following spontaneous subarachnoid hemorrhage: a double-blind, randomized comparison of enoxaparin versus placebo. Clin Neurol Neurosurg 2004;106(2):97-103. [PubMed: 15003298]

139. Muizelaar JP, Zwienenberg M, Rudisill NA, Hecht ST. The prophylactic use of transluminal balloon angioplasty in patients with Fisher Grade 3 subarachnoid hemorrhage: a pilot study. J Neurosurg 1999;91(1):51-58. [PubMed: 10389880]

140. Nolan CP, Macdonald RL. Can angiographic vasospasm be used as a surrogate marker in evaluating therapeutic interventions for cerebral vasospasm? Neurosurg Focus 2006;21(3):E1. [PubMed: 17029333]

141. Keyrouz SG, Diringer MN. Clinical review: Prevention and therapy of vasospasm in subarachnoid hemorrhage. Crit Care 2007;11(4):220. [PubMed: 17705883] 
142. Koebbe CJ, Veznedaroglu E, Jabbour P, Rosenwasser RH. Endovascular management of intracranial aneurysms: current experience and future advances. Neurosurgery 2006;59(5 Suppl 3):S93-102. [PubMed: 17053622]

143. Kirmani JF, Alkawi A, Ahmed S, Janjua N, Khatri I, Divani AA, et al. Endovascular treatment of subarachnoid hemorrhage. Neurol Res 2005;27(Suppl 1):S103-7. S103-S107. [PubMed: 16197834]

144. Lam JM, Smielewski P, Czosnyka M, Pickard JD, Kirkpatrick PJ. Predicting delayed ischemic deficits after aneurysmal subarachnoid hemorrhage using a transient hyperemic response test of cerebral autoregulation. Neurosurgery 2000;47(4):819-825. [PubMed: 11014420]

145. Czosnyka M, Smielewski P, Czosnyka Z, Piechnik S, Steiner LA, Schmidt E, et al. Continuous assessment of cerebral autoregulation: clinical and laboratory experience. Acta Neurochir Suppl 2003;86:581-5. 581-585. [PubMed: 14753510]

146. Jaeger M, Schuhmann MU, Soehle M, Nagel C, Meixensberger J. Continuous monitoring of cerebrovascular autoregulation after subarachnoid hemorrhage by brain tissue oxygen pressure reactivity and its relation to delayed cerebral infarction. Stroke 2007;38(3):981-986. [PubMed: 17272764]

147. Kosnik EJ, Hunt WE. Postoperative hypertension in the management of patients with intracranial arterial aneurysms. J Neurosurg 1976;45(2):148-154. [PubMed: 939973]

148. Kassell NF, Peerless SJ, Durward QJ, Beck DW, Drake CG, Adams HP. Treatment of ischemic deficits from vasospasm with intravascular volume expansion and induced arterial hypertension. Neurosurgery 1982;11(3):337-343. [PubMed: 7133349]

149. DENNY-BROWN D. The treatment of recurrent cerebrovascular symptoms and the question of "vasospasm". Med Clin North Am 1951;35(5):1457-1474. [PubMed: 14862567]

150. Muench E, Horn P, Bauhuf C, Roth H, Philipps M, Hermann P, et al. Effects of hypervolemia and hypertension on regional cerebral blood flow, intracranial pressure, and brain tissue oxygenation after subarachnoid hemorrhage. Crit Care Med 2007;35(8):1844-1851. [PubMed: 17581487]

151. Raabe A, Beck J, Keller M, Vatter H, Zimmermann M, Seifert V. Relative importance of hypertension compared with hypervolemia for increasing cerebral oxygenation in patients with cerebral vasospasm after subarachnoid hemorrhage. J Neurosurg 2005;103(6):974-981. [PubMed: 16381183]

152. Ekelund A, Reinstrup P, Ryding E, Andersson AM, Molund T, Kristiansson KA, et al. Effects of iso- and hypervolemic hemodilution on regional cerebral blood flow and oxygen delivery for patients with vasospasm after aneurysmal subarachnoid hemorrhage. Acta Neurochir (Wien ) 2002;144(7):703-712. [PubMed: 12181704]

153. Muench E, Horn P, Bauhuf C, Roth H, Philipps M, Hermann P, et al. Effects of hypervolemia and hypertension on regional cerebral blood flow, intracranial pressure, and brain tissue oxygenation after subarachnoid hemorrhage. Crit Care Med 2007;35(8):1844-1851. [PubMed: 17581487]

154. Ekelund A, Reinstrup P, Ryding E, Andersson AM, Molund T, Kristiansson KA, et al. Effects of iso- and hypervolemic hemodilution on regional cerebral blood flow and oxygen delivery for patients with vasospasm after aneurysmal subarachnoid hemorrhage. Acta Neurochir (Wien ) 2002;144(7):703-712. [PubMed: 12181704]

155. Muench E, Horn P, Bauhuf C, Roth H, Philipps M, Hermann P, et al. Effects of hypervolemia and hypertension on regional cerebral blood flow, intracranial pressure, and brain tissue oxygenation after subarachnoid hemorrhage. Crit Care Med 2007;35(8):1844-1851. [PubMed: 17581487]

156. Joseph M, Ziadi S, Nates J, Dannenbaum M, Malkoff M. Increases in cardiac output can reverse flow deficits from vasospasm independent of blood pressure: a study using xenon computed tomographic measurement of cerebral blood flow. Neurosurgery 2003;53(5):1044-1051. [PubMed: 14580270]

157. Naidech A, Du Y, Kreiter KT, Parra A, Fitzsimmons BF, Lavine SD, et al. Dobutamine versus milrinone after subarachnoid hemorrhage. Neurosurgery 2005;56(1):21-61. [PubMed: 15617582]

158. Romero CM, Morales D, Reccius A, Mena F, Prieto J, Bustos P, et al. Milrinone as a Rescue Therapy for Symptomatic Refractory Cerebral Vasospasm in Aneurysmal Subarachnoid Hemorrhage. Neurocrit Care. 2008 
159. Fraticelli AT, Cholley BP, Losser MR, Saint Maurice JP, Payen D. Milrinone for the treatment of cerebral vasospasm after aneurysmal subarachnoid hemorrhage. Stroke 2008;39(3):893-898. [PubMed: 18239182]

160. Suzuki S, Jahan R, Duckwiler GR, Frazee J, Martin N, Vinuela F. Contribution of endovascular therapy to the management of poor-grade aneurysmal subarachnoid hemorrhage: Clinical and angiographic outcomes. J Neurosurg 2006;105(5):664-670. [PubMed: 17121125]

161. Brisman JL, Eskridge JM, Newell DW. Neurointerventional treatment of vasospasm. Neurol Res 2006;28(7):769-776. [PubMed: 17164040]

162. Mueller-Kronast N, Jahromi BS. Endovascular treatment of ruptured aneurysms and vasospasm. Curr Treat Options Neurol 2007;9(2):146-157. [PubMed: 17298775]

163. Jestaedt L, Pham M, Bartsch AJ, Kunze E, Roosen K, Solymosi L, et al. The impact of balloon angioplasty on the evolution of vasospasm-related infarction after aneurysmal subarachnoid hemorrhage. Neurosurgery 2008;62(3):610-617. [PubMed: 18301345]

164. Zwienenberg-Lee M, Hartman J, Rudisill N, Muizelaar JP. Endovascular management of cerebral vasospasm. Neurosurgery 2006;59(5 Suppl 3):S139-S147. [PubMed: 17053596]

165. Cross DT III, Moran CJ, Angtuaco EE, Milburn JM, Diringer MN, Dacey RG Jr. Intracranial pressure monitoring during intraarterial papaverine infusion for cerebral vasospasm. AJNR Am J Neuroradiol 1998;19(7):1319-1323. [PubMed: 9726476]

166. Milburn JM, Moran CJ, Cross DT III, Diringer MN, Pilgram TK, Dacey RG Jr. Effect of intraarterial papaverine on cerebral circulation time. AJNR Am J Neuroradiol 1997;18(6):10811085. [PubMed: 9194435]

167. Sayama CM, Liu JK, Couldwell WT. Update on endovascular therapies for cerebral vasospasm induced by aneurysmal subarachnoid hemorrhage. Neurosurg Focus 2006;21(3):E12. [PubMed: 17029336]

168. Brisman JL, Eskridge JM, Newell DW. Neurointerventional treatment of vasospasm. Neurol Res 2006;28(7):769-776. [PubMed: 17164040]

169. Fraticelli AT, Cholley BP, Losser MR, Saint Maurice JP, Payen D. Milrinone for the treatment of cerebral vasospasm after aneurysmal subarachnoid hemorrhage. Stroke 2008;39(3):893-898. [PubMed: 18239182]

170. Hirsh LF. Intra-arterial nitroprusside treatment of acute experimental vasospasm. Stroke 1980;11:601-605. [PubMed: 7210065] 


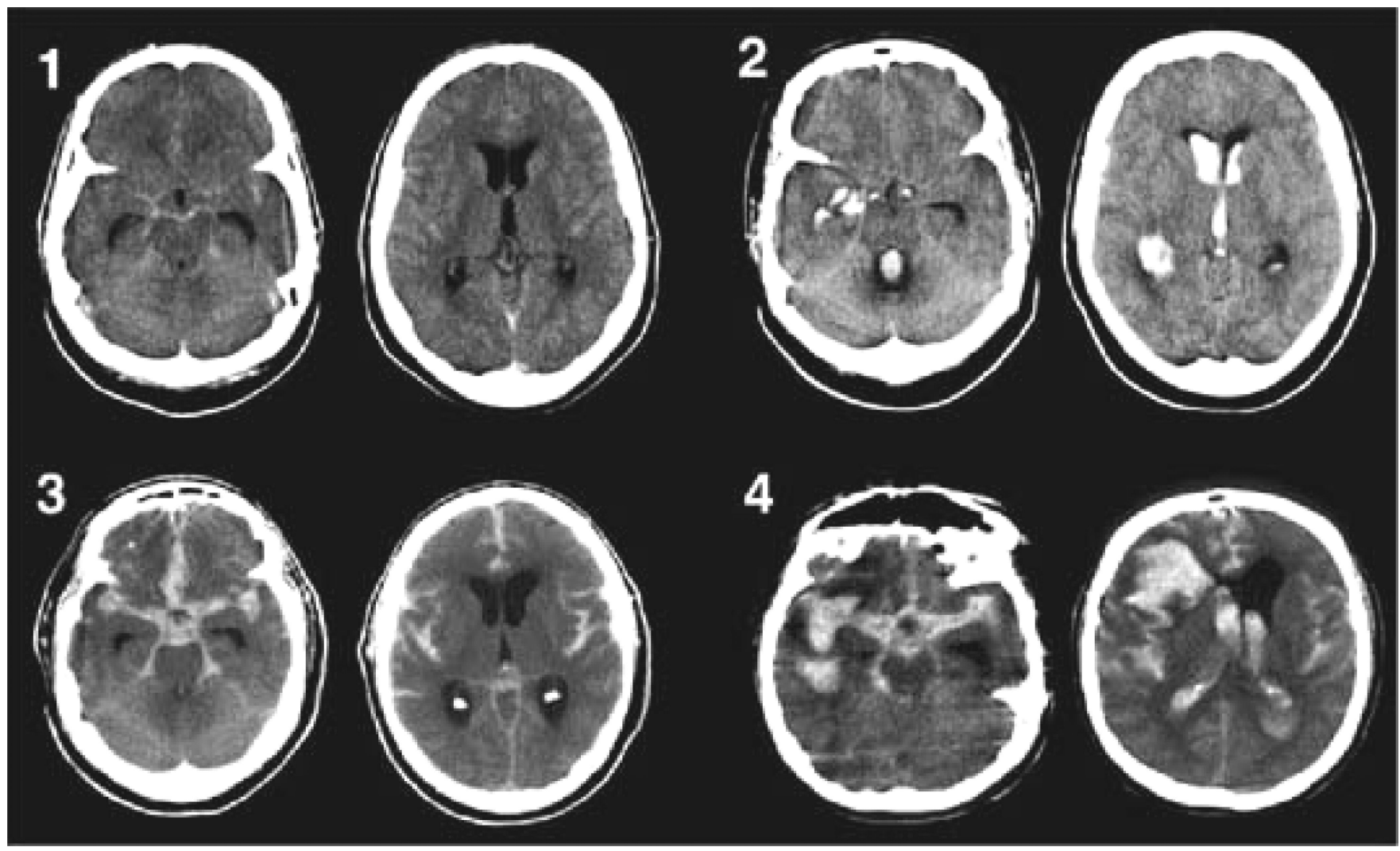

Figure 1.

The Modified Fisher CT rating scale: Grade 1 (minimal or diffuse thin SAH without IVH), indicating low risk for symptomatic vasospasm; Grade 2 (minimal or thin SAH with IVH) and Grade 3 (thick cisternal clot without IVH), indicating intermediate risk for symptomatic vasospasm; and Grade 4 (cisternal clot with IVH), indicating high risk for symptomatic vasospasm. Reproduced with permission from Claassen J, Bernardini GL, Kreiter K, Bates J, Du YE, Copeland D, Connolly ES Jr, Mayer SA: Effect of cisternal and ventricular blood on risk of delayed cerebral ischemia after subarachnoid hemorrhage: the Fisher scale revisited. Stroke 32:2012-2020, 2001. From: Frontera: Neurosurgery, Volume 59(1).July 2006.21-27 


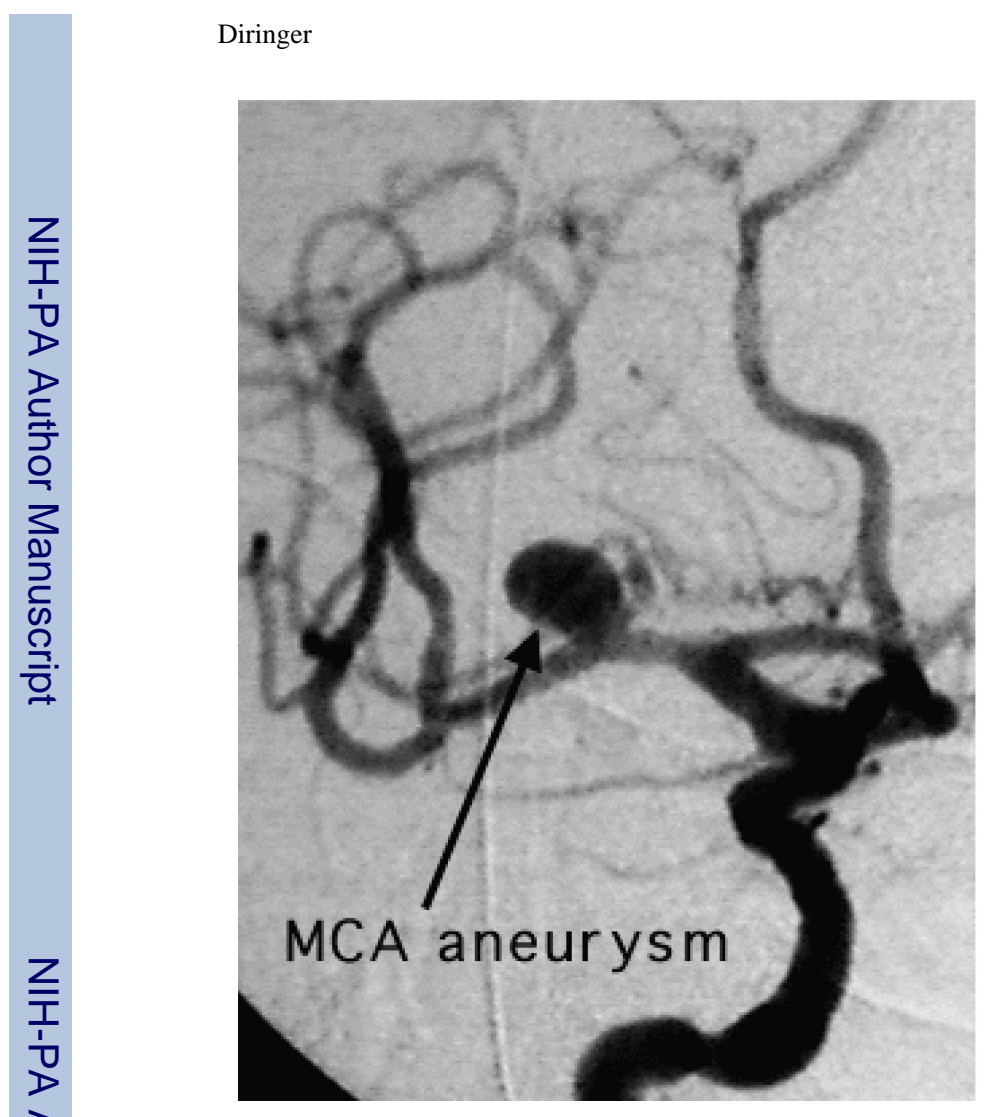

Figure 2.

Middle cerebral artery aneurysm before and after endovascular coiling

\section{Coils in aneurysm}

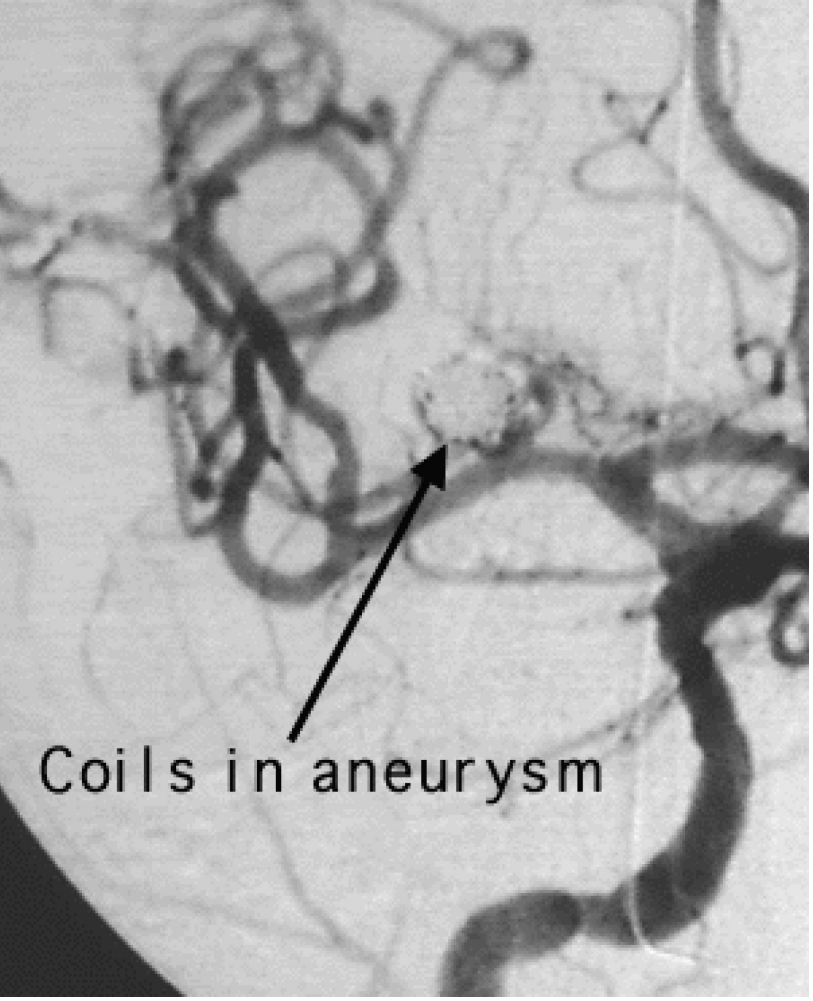



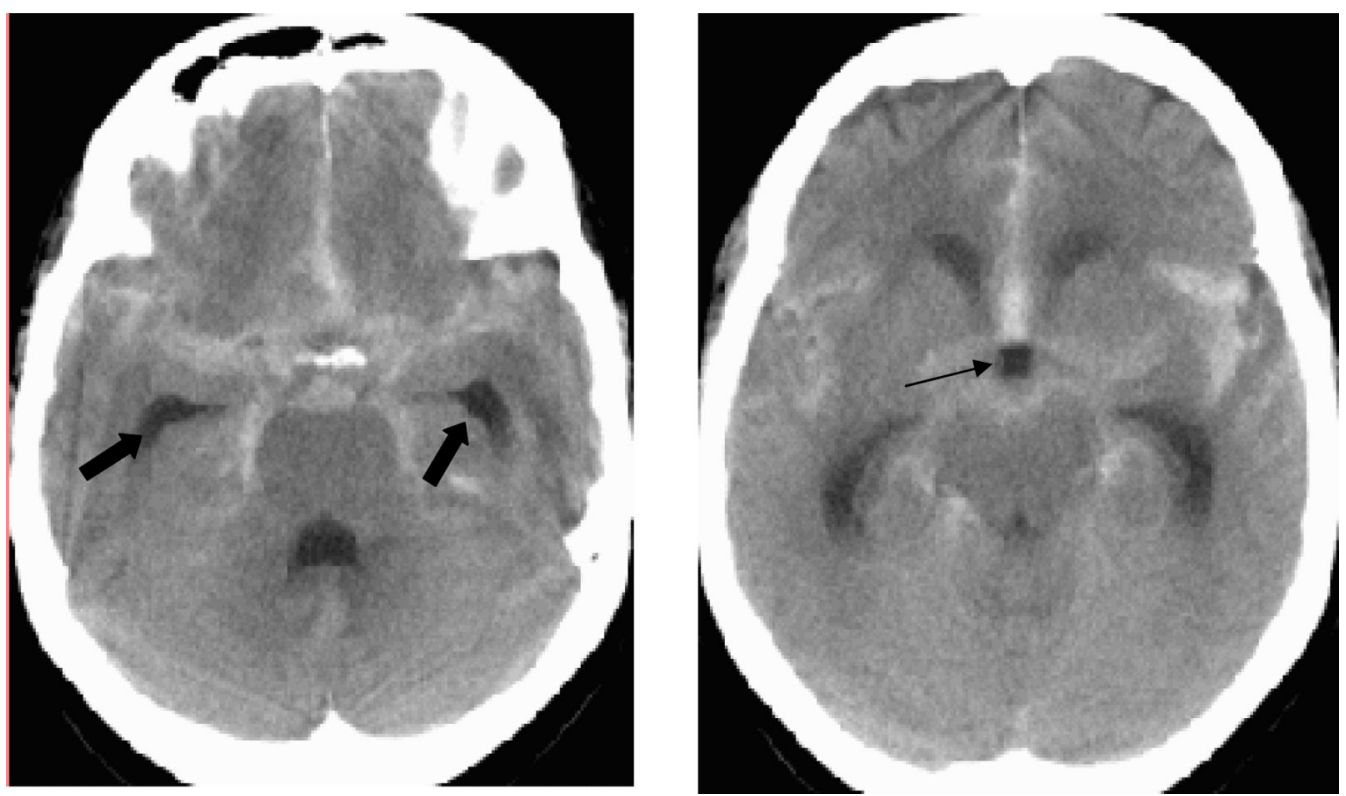

Figure 3.

CT scan of patient with SAH showing early hydrocephalus. Note the enlargement of the temporal horns of the lateral ventricle (thick arrows) and ballooning of the third ventricle (thin arrow). 

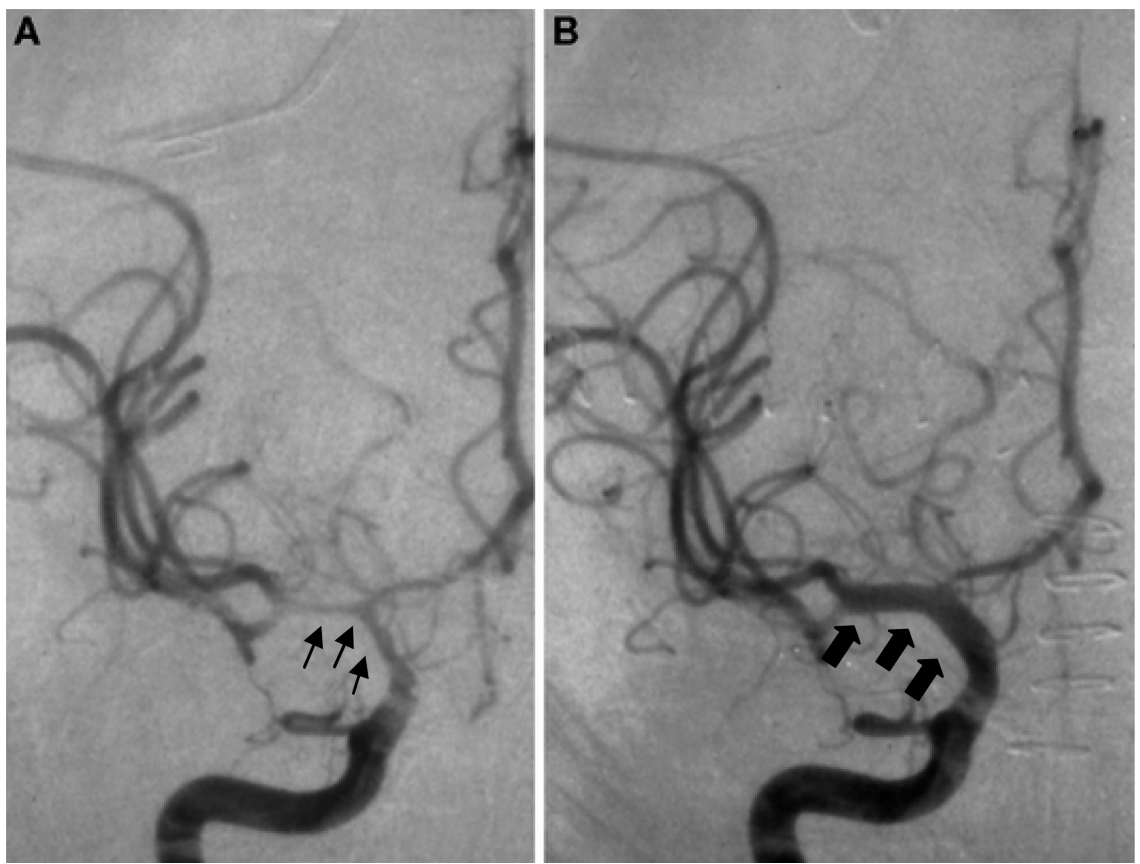

Figure 4.

Vasospasm before and after angioplasty. A - angiogram with vasospasm in the middle cerebral artery territory (thin arrows); B - angiogram after angioplasty with improvement in vasospasm (thick arrows) 
Table 1

Clinical grading scales following subarachnoid hemorrhage.

\begin{tabular}{|c|c|c|c|}
\hline & Hunt and Hess scale (36) & World Federation of Neurological Surgeons Scale (37) \\
\hline Grade & Symptoms & Glasgow Coma Scale & Motor deficits \\
\hline I & Asymptomatic or mild headache & 15 & Absent \\
\hline II & $\begin{array}{c}\text { Moderate to severe headache, nuchal rigidity, with or without cranial } \\
\text { nerve deficits }\end{array}$ & $14-13$ & Absent \\
\hline III & Confusion, lethargy or mild focal symptoms & $14-13$ & Present \\
\hline IV & Stupor and/or hemiparesis & $12-7$ & Present or absent \\
\hline V & Comatose and/or extensor posturing & $6-3$ & Present or absent \\
\hline
\end{tabular}

